\title{
Health risk assessment at mass gatherings: a report of the camel festival in Saudi Arabia
}

Kingsley Bieh, ${ }^{1}$ Ahmed ElGanainy, ${ }^{1}$ Saber Yezli, ${ }^{1}$ Mamunur Malik, ${ }^{2}$ Hani Aziz Jokhdar, ${ }^{3}$ Abdullah Asiri ${ }^{4}$ and Badriah Alotaibi ${ }^{1}$

${ }^{1}$ Global Center for Mass Gatherings Medicine, Riyadh, Saudi Arabia. ${ }^{2}$ World Health Organization Regional Office for the Eastern Mediterranean, Cairo, Egypt. ${ }^{3}$ Deputy Minister for Public Health, Ministry of Health, Saudi Arabia. ${ }^{4}$ Assistant Deputy Minister for Public Health, Ministry of Health, Saudi Arabia, IHR National Focal Point. (Correspondence to: Kingsley Bieh: blezor@moh.gov.sa).

\begin{abstract}
Background: The King Abdel Aziz Camel Festival in Riyadh, Saudi Arabia, aims to showcase the socio-cultural and economic roles of camels in the Middle East, and attracts visitors from many countries in the Region.

Aims: Potentially, the gathering of large numbers of people and animals within a specified geographical area during the annual festival has important implications for public safety, health security and legacy. Thus, the Ministry of Health through the Global Center for Mass Gathering Medicine, Saudi Arabia, conducted a health risk assessment for the 2017 Camel Festival. This paper summarizes the risk assessment process and highlights the findings and recommendations of the risk assessment.

Methods: Using an all-hazard approach, the Jeddah tool (derived from the World Health Organization Eastern Mediterranean Regional Office's health emergency risk assessment tool) was adapted to conduct the risk assessment. The tool stipulates that risk is directly proportional to the product of hazard magnitude and vulnerability and inversely related to capacity.

Results: External causes of morbidity and mortality, such as fires and road traffic accidents, were categorized as high risk hazards. In contrast, brucellosis, foodborne diseases and Middle East Respiratory Syndrome were ranked moderate risk hazards. Rift Valley fever was ranked low risk hazard.

Conclusions: The camel festival risk assessment highlights the need for an all-hazard approach to mass gatherings risk assessment. There is a need for multi-sectorial collaboration to strengthen the existing capacity, including disease surveillance.

Keywords: Mass gatherings, risk assessment, zoonosis, Jeddah tool, Saudi Arabia

Citation: Bieh K; ElGanainy A; Yezli S; Malik M; Aziz Jokhdar H; Asiri A; et al. Health risk assessment at mass gatherings: a report of the camel festival in Saudi Arabia. East Mediterr Health J. 2019;25(9):647-655. https://doi.org/10.26719/emhj.18.071

Received: 31/01/18; accepted: 30/07/18

Copyright (C) World Health Organization (WHO) 2019. Some rights reserved. This work is available under the CC BY-NC-SA 3.o IGO license (https:// creativecommons.org/licenses/by-nc-sa/3.o/igo).
\end{abstract}

\section{Introduction}

The World Health Organization (WHO) defines mass gatherings (MGs) as events attended by sufficient number of people to strain the planning and response resources of the community, state or nation (1). Saudi Arabia (KSA) hosts two major perennial international religious MGs; the Hajj and Umrah Muslim pilgrimages (2). In addition, Saudi Arabia regularly hosts other MGs including sporting and cultural events. One such event is the annual Camel Festival (King Abdel Aziz Festival), which has provided a medium for showcasing the best breeds of camels in the Gulf region since the inaugural event in 2000 (3). The festival aims to highlight the important role of camels in the day-to-day life of Arabs in the Gulf and to help preserve the purity of camel breeds in the region. On average, two million visitors and 15000 camels from most Gulf countries participate in the month-long regional MG. Some highlights of the festival include cultural displays, camel racing, dances and the highly celebrated and financially rewarding "camel beauty contest" (3). Owners of the contest's winning camels may receive up to SR25 million (US\$ 6.6 million) in prize money.
Communicable diseases, injuries and environmental hazards, such as storms and fires, could constitute significant public health threats during any festival. This may have far-reaching consequences, including the threats to public safety and health security, the strain on public health infrastructures and the resultant reputational impact. In addition, since international travel contributes to disease outbreaks and transmission of infectious pathogens during MGs (4), and given the regional dimension of the festival, the latter can potentially lead to spread of pathogens and diseases to neighbouring countries. More so, the gathering of animals and humans at the same location may create unique opportunities for the spread of zoonotic diseases such as the Middle East Respiratory Syndrome Coronavirus (MERS-CoV) and brucellosis. Concerns over possible festival-associated outbreak of MERS led to the suspension of the last two editions of the festival by the Saudi authorities. An outbreak of MERS at the festival would have important public health consequences including its potential spread to areas not previously affected by the virus as well as a negative impact on the festival's overall reputation. 
Minimizing or eliminating risks is the goal of public health preparedness for MGs (5). Within this framework, identification of the population's vulnerability to health risks and hazards and assessment of the readiness of the health system to mitigate the occurrence and impact of health threats are necessary requirements for planning and decision-making, including the distribution of limited health resources (5). Hence, the Saudi Ministry of Health $(\mathrm{MoH})$, through the Global Centre for Mass Gatherings Medicine (GCMGM), which is also a WHO Collaborating Center for Mass Gatherings, conducted a risk assessment of the Camel Festival during 1-7 March 2017, with the aims of identifying potential hazards that pose a threat to public health, assessing the risks to health security and legacy and recommending practical strategies for preventing, reducing or eliminating public health risks that may be associated with this event. This article summarizes the risk assessment process and highlights the findings and recommendations of the risk assessment.

\section{Context and organization of health services}

The camel festival was held from the 19 March to 15 April 2017 within a $37 \mathrm{~km}^{2}$ area of predominantly uninhabited desert land, situated about $100 \mathrm{~km}$ northeast of the capital Riyadh. During the festival, temporary housing is provided for camels separate from the human living area, which is made up of make-shift tents and located about $8 \mathrm{~km}$ away from the contest area. Food vendors and temporary eateries are located around the contest area. However, individuals do also cook their own meals when they retire to the tents.

The $\mathrm{MoH}$ has two designated temporary primary health centres (PHCs) for the event and both health units are located close to the contest area. A 50-bed capacity $\mathrm{MoH}$ hospital (Ramah hospital) located within $20 \mathrm{~km}$ radius of the festival venue is also designated for health service delivery during the event. The hospital is operational all-year round, provides round-the-clock services and has a helipad to facilitate the air transfer of critically ill patients to other hospitals in Riyadh. Facility records show that 30 doctors (1 consultant, 11 specialists and 16 residents) and 57 nurses provide health services in Ramah hospital for an estimated 28 ooo local population off-festival season. Nevertheless, the $\mathrm{MoH}$ posted 9 doctors, 17 nurses, 4 infection control officers and 5 epidemiologists to boost existing workforce capacity during the 2017 festival.

\section{Risk assessment process and findings}

The Jeddah Religious Mass Gatherings Risk Assessment tool evolved from the Health Emergency Risk Assessment tool (HERA) and was developed by the World Health Organization Eastern Mediterranean Regional Office (WHO/EMRO). The HERA protocol offered a simplified and flexible guide for countries to conduct health risk assessments in many settings at national and/or local level as part of the risk reduction strategy. The tool has been utilized for health emergency risk assessment in various countries in the Region, including Saudi Arabia (for the strategic Hajj health risk assessment). In January 2017, the GCMGM collaborated with WHO/EMRO to conduct an international consultation on mass gatherings health risk assessment tools, in Jeddah. The consultation recommended the adoption of the tool as the Jeddah tool for religious mass gatherings risk assessment following the standardization of the scoring system.

The tool expresses a functional correlation between risks, vulnerabilities and capacities in the contexts of hazards to provide data for planning as: Risk $\infty$ (Hazards X Vulnerabilities)/Capacities. The UNISDR defines hazard as, "a dangerous phenomenon, substance, human activity or condition that may cause loss of life, injury or other health impacts, property damage, loss of livelihoods and services, social and economic disruption, or environmental damage". In addition, it refers to vulnerability as, "the characteristics and circumstances of a community, system, or asset that makes it susceptible to the damaging effects of a hazard" and defines capacity as, "the combination of all the strengths, attributes, and resources available within a community, society, or organization that can be used to achieve agreed goals" (6). The tool's risk assessment process consists of four phases, namely context evaluation, setting-up, assessment and communication (Figure 1).

An all-hazard approach, which was guided by the Jeddah tool, was utilized for the camel festival risk

Figure 1 The implementation steps for health emergency risk assessment

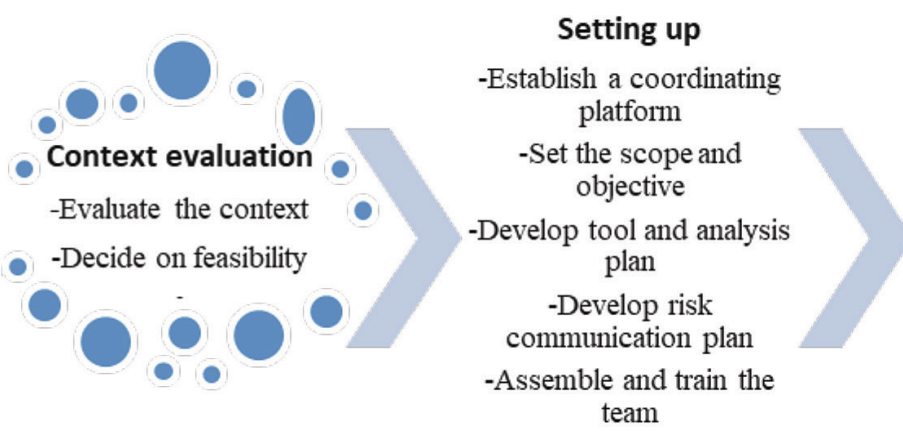

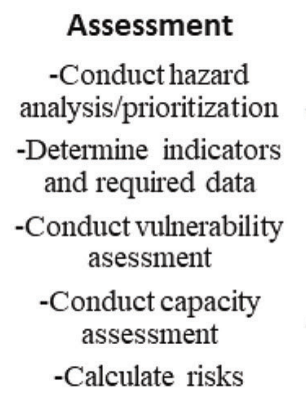

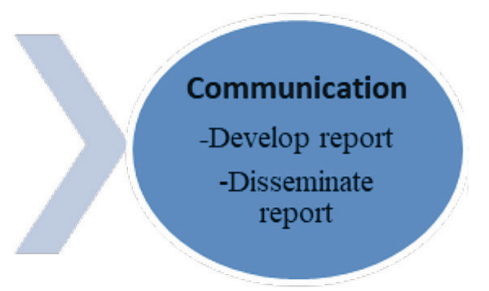


assessment process. An assessment team that includes epidemiologists, public health experts and disaster management consultants conducted the assessment with the guidance and support of the MoH's Command and Control Committee. The latter is composed of subject matter experts and heads of relevant $\mathrm{MoH}$ departments, which provides leadership for the public health preparedness and response operations of the $\mathrm{MoH}$. The assessment team consulted subject matter experts and explored historical data in published literature and MoH's databases and reports to develop a list of potential hazards. Then hazards were prioritized based on the frequency of their occurrence, the magnitude of previous event in terms of morbidity and mortality and the proportion of the population that could be exposed to the hazard (Table 1).

The benchmark for the number of prioritized hazards that was included in the assessment was a function of resource availability and the main $\mathrm{MoH}$ priorities. Subsequently, vulnerability and capacity indicators were developed for the prioritized hazards. For each indicator, we established a categorization score on an ordinal scale ranging from $1-5$, with 5 assuming the highest risk for both vulnerabilities and capacities. Having considered the relative importance of individual indicators, we assigned weights based on pre-established criteria, and obtained the risk score from the product of weight and categorization score (Table 2). Then the sum of risk score for each hazard was calculated and risk was categorized risk as "Low" "Moderate" and "High" using the 34th, 67th and 10oth percentiles respectively, of the range between the lowest and highest possible score (Table 1). Information on each subject area covered during the risk assessment is described below.

\begin{tabular}{|c|c|c|c|c|c|c|}
\hline Hazard & $\begin{array}{l}\text { Frequency } \\
\text { (F) } \\
\text { Min 1 } \\
\text { Max } 5\end{array}$ & $\begin{array}{c}\text { Magnitude } \\
\text { (M) } \\
\text { Min } 1 \\
\text { Max } 5\end{array}$ & $\begin{array}{c}\text { Exposure }^{c} \\
\text { (E) } \\
\text { Min 1 } \\
\text { Max } 3\end{array}$ & $\begin{array}{l}\text { Prioritization } \\
\text { Score } \\
\text { (FXMXE) d }^{\text {FXM }}\end{array}$ & Vulnerability & Capacity \\
\hline $\begin{array}{l}\text { External causes of } \\
\text { morbidity } \\
\text { and mortality }\end{array}$ & 5 & 5 & 3 & 75 & $\begin{array}{l}\text { - Over-speeding vehicles } \\
\text { associated with RTA } \\
\text { - RTA account for } 20 \% \\
\text { of occupied beds and } \\
81 \% \text { of deaths in } \mathrm{MOH} \\
\text { hospitals } \\
\text { - Bites and stings } \\
\text { common in deserts } \\
\text { - Regional conflicts } \\
\text { associated with terror } \\
\text { attacks }\end{array}$ & $\begin{array}{l}\text { - Updated national } \\
\text { emergency plan } \\
\text { - Need for festival } \\
\text { emergency plan } \\
\text { - Need to strengthen } \\
\text { interagency } \\
\text { coordination } \\
\text { - Availability of trained } \\
\text { staff and emergency } \\
\text { vehicles }\end{array}$ \\
\hline MERS-CoV & 4 & 5 & 3 & 60 & $\begin{array}{l}\cdot>85 \% \text { of cases reported } \\
\text { in KSA } \\
\text { - } 40 \% \text { case fatality rate } \\
\text { - Camels are reservoirs } \\
\text { - Human contact with } \\
\text { camels during festival } \\
\text { - Consumption of } \\
\text { unpasteurised diary } \\
\text { product common }\end{array}$ & $\begin{array}{l}\text {-Well-established } \\
\text { national surveillance } \\
\text { - Improved IPC practices } \\
\text { - Good interagency } \\
\text { communication and } \\
\text { collaboration } \\
\text { - Designated MERS-CoV } \\
\text { management centre }\end{array}$ \\
\hline Foodborne diseases & 5 & 4 & 2 & 40 & $\begin{array}{l}\text { - Major threat at mass } \\
\text { gatherings } \\
\text { - Patronage of vended } \\
\text { food }\end{array}$ & $\begin{array}{l}\text { - Need to strengthen food } \\
\text { safety regulations }\end{array}$ \\
\hline Brucellosis & 5 & 3 & 2 & 30 & $\begin{array}{l}\text { - Endemic in KSA } \\
\text { - } 12.8 \text { cases/100 } 000 \\
\text { population in } 2016 \\
\text { - Consumption of } \\
\text { unpasteurised diary }\end{array}$ & $\begin{array}{l}\text { - Strong interagency } \\
\text { collaboration for } \\
\text { prevention and control }\end{array}$ \\
\hline Rift Valley fever & 2 & 4 & 3 & 24 & $\begin{array}{l}\text { - Known zoonosis } \\
\text { - } 886 \text { suspected cases } \\
\text { of RVF and } 13.9 \% \text { case } \\
\text { fatality rate in } 2000 / 2001 \\
\text { - Reported outbreak in } \\
\text { Niger } 2016 \\
\text { - Tendency for rapid } \\
\text { international spread }\end{array}$ & $\begin{array}{l}\text { - Existing national } \\
\text { surveillance }\end{array}$ \\
\hline
\end{tabular}




\begin{tabular}{|c|c|c|c|c|}
\hline Indicator & Indicator value & $\begin{array}{l}\text { Categorization } \\
\text { score }\end{array}$ & Weight $^{1}$ & Risk score \\
\hline \multicolumn{5}{|c|}{ Vulnerability indicators } \\
\hline $\begin{array}{l}\text { 1. Contact of participants } \\
\text { with reservoir }\end{array}$ & $\begin{array}{l}\text { No } \\
\text { Yes }\end{array}$ & $\begin{array}{l}\mathrm{No}=1 \\
\mathrm{Yes}=5\end{array}$ & 4 & $\begin{array}{l}\text { Total } 20 \\
\text { Min } 5 \\
\text { Max } 20\end{array}$ \\
\hline 2. Case fatality rate of MERS & $\begin{array}{c}<5 \%=1 \\
5-10 \%=2 \\
11-30 \%=3 \\
31-49 \%=4 \\
\geq=5\end{array}$ & 4 & 3 & $\begin{array}{c}\mathbf{1 2} \\
\text { Min } 3 \\
\text { Max } 15\end{array}$ \\
\hline $\begin{array}{l}\text { 3. Current national MERS } \\
\text { outbreak }\end{array}$ & $\begin{array}{l}\text { No } \\
\text { Yes }\end{array}$ & $\begin{array}{c}\text { No }=1 \\
\text { Yes }=5\end{array}$ & 3 & $\begin{array}{c}15 \\
\text { Min } 4 \\
\operatorname{Max} 15\end{array}$ \\
\hline \multicolumn{5}{|c|}{ Capacity indicator } \\
\hline $\begin{array}{l}\text { 4. Existence of infection } \\
\text { control protocol in } \\
\text { healthcare facilities }\end{array}$ & $\begin{array}{l}\text { 1. Infection control protocol for droplet/air-borne infectious } \\
\text { diseases are fully developed, tested, regularly updated } \\
\text { and widely disseminated among staff. } \\
\text { 2. Infection control protocol for droplet/air-bor ne infectious } \\
\text { diseases partially developed and/or untested/infrequently } \\
\text { updated/ not widely disseminated among staff. } \\
\text { 3. Infection control protocol for droplet/air-borne infectious } \\
\text { diseases is not developed }\end{array}$ & $\begin{array}{l}\mathbf{1}=\mathbf{1} \\
2=3 \\
3=5\end{array}$ & 4 & $\begin{array}{c}\mathbf{4} \\
\operatorname{Min} 4 \\
\operatorname{Max} 20\end{array}$ \\
\hline
\end{tabular}

1: Vulnerability weighting assigned based on relationship between indicator value and risk (5 consistent cause-effects, 4 variable cause-effects, 3 consistent non-causal, 2 variable non-causal, 1 potential). Capacity weighting assigned based on mitigating impact: 5-variable prevents hazard occurrence, 4-variable limits the direct threat of hazards 3-variable reduces the magnitude of an effect eg case management, 2 indirectly influences risk, 1 potential impact on risk

\section{Zoonotic diseases}

Due to the potential close proximity between camels and humans during the festival, zoonotic diseases including MERS, Rift Valley fever (RVF) and brucellosis were prioritized in the risk assessment process. As of 1 November 2017, the Saudi MoH has reported 1686 cases of MERS in the country and a mortality rate of $\sim 40 \%$ among cases (7). Although the vast majority (>80\%) of MERS cases have been reported in Saudi Arabia since the onset of the epidemic in 2012, other countries in the Middle East such as Qatar, Oman, Kuwait and Islamic Republic of Iran have also reported cases of the disease $(7,8)$. Dromedary camels, which constitute about $95 \%$ of the world's camel population and the predominant breed in the Gulf are a recognized reservoir of the virus (9). Potentially, infected camels shed MERS-CoV through their eyes, nasal secretions, faeces, urine and dairy products (8). The typical clinical manifestations of MERS range from mild respiratory diseases to severe respiratory illnesses and multi-organ failure, and adults aged 60 years and above, as well as those with coexisting medical conditions are at risks of severe disease $(8,9)$.

The Saudi $\mathrm{MoH}$ has a regularly updated plan for the control and management of MERS in the country. Trained surveillance and response teams equipped with appropriate tools, including specialized ambulances for transfer of suspected cases of infectious diseases and personal protective equipment, are deployed across Saudi Arabia (2). The Saudi Ministry of Environment, Water and Agriculture (MEWA) coordinates the surveillance and response plan for animal infections in the country and has established a specialized team to be involved in the festival. The Saudi $\mathrm{MoH}$ pre-designated MERS Center at Prince Mohammed Bin Abdul-Aziz hospital, which is located $127 \mathrm{~km}$ from the festival, would serve as isolation and treatment area for suspected cases of MERS. Due to poor understanding of the mechanism of transmission of MERS-CoV, potential for asymptomatic infection to go unnoticed, and the increased possibility for contact between camels and humans during the festival, the likelihood of a festival-associated MERS outbreak and transmission was high. However, balancing these vulnerabilities with the improved surveillance and response capabilities of the $\mathrm{MoH}$ across the country, the risk assessment concluded that there was a moderate risk of a festival-associated outbreak of MERS.

RVF is a zoonotic haemorrhagic viral disease transmitted to humans via infected animals and mosquitoes (10). RVF causes abortions and deaths in animals and human infections may manifest as low grade fever, abdominal pain and diarrhoea, intravascular coagulopathy and multi-organ failure $(10,11)$. The last known outbreak of RVF in Saudi Arabia was reported in 2000, which is thought to have been imported from the horn of Africa (11). From 26 August 2000 to 22 September 2001, the MoH reported 886 suspected cases of RVF and a mortality rate of $13.9 \%$ among cases (12). Currently, no outbreak of the disease has been reported in the Gulf, but 
RVF was reported in August 2016 in Niger (10). Due to the rarity of the disease in recent years and the high level readiness of the country to detect, report and responds to RFV cases through an active disease surveillance system operated by MEWA, the risk of a festival-associated outbreak of RVF was estimated to be low.

Brucellosis is an endemic zoonotic disease in Saudi Arabia, which causes unspecific symptoms in humans, including fever and musculoskeletal pain (13). With improved control activities, the national incidence rate for Saudi Arabia reduced from 22.9/100 000 population in 2004 to $12.8 / 100000$ population in $2016(13,14)$. Disease transmission persists due to continued importation of livestock from endemic countries and the consumption of unpasteurized milk especially in the rural areas of Saudi Arabia. Brucellosis is among the monthly notifiable diseases in Saudi Arabia and an animal vaccination programme for the disease is in place through MEWA (13). With increased likelihood of consumption of unpasteurized milk by attendees during the festival and the endemicity of the disease in the country, the risk assessment estimated a moderate risk of festivalassociated transmission of brucellosis.

\section{Foodborne diseases}

Foodborne diseases outbreaks are among the leading public health concerns at festivals and MGs worldwide, including the Hajj (15-17). In 2015, 52 foodborne diseases outbreaks were reported in Riyadh, of which the majority were food poisoning outbreaks (14). Cholera outbreaks are of particular concern during the festival, since outbreaks were being reported in both Yemen and Iraq at the time of the assessment. As such, these countries represented potential sources of transmission to other neighbouring countries, including Saudi Arabia. There is limited information regarding other foodborne diseases pathogens that are potential threats at the festival. However, in a recent study, which explored the enteric pathogens associated with diarrhoeal diseases among pilgrims during 2011-2013 Hajj seasons, bacteria were detected in $82.9 \%$ of positive samples. Viruses and parasites were detected in $6.1 \%$ and $5.3 \%$ of positive samples respectively. The main pathogens associated with severe symptoms were salmonella spp, shigela/enteroinvasive E.coli and enterotoxigenic E.coli (18). The $\mathrm{MoH}$ plays a minor role in regulating food safety practices during the festival. In general, food safety regulation, including at MGs, is contracted to private firms by the municipality and there are concerns about the efficiency of their accreditation process (19). At the festival, poor storage of cooked food by participants living in tents may increase their vulnerability to foodborne diseases, and the patronage of potentially contaminated vended food in the contest area may increase the likelihood of foodborne diseases outbreaks. Overall, a moderate risk of foodborne diseases outbreak was estimated for the camel festival.

\section{External causes of morbidity and mortality}

Traffic accidents, acts of terror and environmental hazards, such as fire emergencies and storms may constitute significant threats to the MG and result in mass-casualty incidents. Road traffic accid ents (RTAs) account for $20 \%$ of occupied beds and $81 \%$ of deaths in $\mathrm{MoH}$ hospitals in Saudi Arabia (20). Riyadh is among the regions with the highest RTAs rates in the country and the demographic profile of expected attendees (mostly young males) fits the most vulnerable risks groups in Saudi Arabia for RTAs. Excessive speeding is the most frequent cause of RTAs, and this may come to bear in a low-traffic open desert area where the event will be held. Over-speeding and car racing by exuberant youths attending the festival may result in high impact collisions and thus potential debilitating injuries and increased mortality.

Although the average day time temperatures during the festival are expected to be high (around 30 degrees Celsius), severe heat illnesses, such as heat stroke and heat exhaustion, are unlikely among a predominantly Arab population that is acclimatized to such conditions. However, high winds and storms, which were forecasted by the Saudi Presidency of Meteorology and Environment to occur in early and mid-April 2017, could result in structural collapse and injuries. Smoking and personalized cooking of meals in make-shift tents may increase the risk of fire emergencies. Additionally, due to the ongoing conflicts in Iraq, Syrian Arab Republic and Yemen, the disaster and humanitarian crisis index for Saudi Arabia has risen by three fold since 2015 (21). Based on the above, the assessors estimated a high risk of masscasualty incidents during the festival.

Furthermore, certain types of snakes and scorpions are typically found in desert areas and these may constitute public health threats during the festival (22). A study showed that most cases of snake bites in Riyadh occur in the lower limbs and are caused by cerastes gasperettii (23). In a five-year period (2005-2010), there were 1019 cases of snake bites, including one fatality in Riyadh (23). With reported lowest incidence of snake bites in March/April and the low case-fatality rate, assessors therefore estimated a low risk of snake bite-related threats during the festival.

\section{Public health measures}

The MoH collaborated with MEWA to implement appropriate surveillance and response measures for zoonotic diseases during the festival. Only healthy camels are allowed to participate in the Camel Festival; this implies that their vaccination status are checked and kept up to date. The history of vaccination with rabies and brucellosis is tracked nationally. However, the tracking of vaccination status for imported camels depends on the epidemiological situation at the country of origin of the camel. Veterinary inspectors at Saudi points of entry routinely check the health status of arriving camels. A health 
certificate is required at the point of entry but the items listed, including vaccination requirements, vary with the epidemiological situation of the country of origin of the arriving camels. Among others, the Saudi veterinary vaccination programme targets brucellosis, cowpox and rabies. Routine camel vaccination for anthrax is not available, since the disease has not been reported among camels in the country. As rare diseases, scabies, tick bites and fungal infection in camels and humans were not prioritized during the risk assessment.

The MEWA conducted rapid screening tests for MERS-CoV as mandatory requirement for participation of camels in the festival. All tested camels were tagged for distinction from unscreened camels, which potentially entered the festival area illegally. Of 13092 camels that were screened for MERS-CoV, 70 camels tested positive by RT-PCR and were excluded from the festival. Overall, 22 suspected human cases of MERS were isolated and screened at Ramah hospital. All 22 cases tested negative for MERS-CoV but one case tested positive for Influenza A (H1NI). All surveillance data was reported through the Health Electronic Surveillance Network (HESN). This is a web-based electronic portal, implemented country-wide for the control of specific notifiable diseases, including MERS. It facilitates real-time reporting, follow-up of laboratory investigations and management of suspected cases. Overall, there were 5180 outpatient consultations, 127 hospital admissions, 11250 emergency visits, including 45 scorpion bite cases and 375 RTA-related trauma cases in Ramah hospital during the festival. This represented about a fivefold rise in the number of RTArelated trauma cases from off-season hospital records. There were no reports of food-borne diseases outbreaks during the festival.

\section{Protecting health security and legacy}

The emergency health risk assessment identified zoonotic diseases, food borne diseases and mass-casualty incidents as the most important hazards that may threaten public safety and health security during the camel festival. Suspension of the event invariably guarantees elimination of health risks. However, the socio-cultural and economic importance of the festival makes continuous ban unrealistic and thus creates a need for the recommendation of practical strategies for mitigating health risks.

The risks of festival-associated outbreak of MERS probably rank highest among the zoonosis due to the relatively high case-fatality rate of the disease and the resultant damaging impact on legacy. Since there are yet no specific treatments or effective vaccines for MERS globally, appropriate prevention and control measures are required during the festival. With evidence of active viral shedding in nasal and oral secretions of camels, testing of nasopharyngeal samples for potential infections and exclusion of camels with positive test results from the festival to reduce the risks of festival associated outbreak of the disease is warranted. Refresher courses regarding disease surveillance, infection prevention and control
(IPC) and case-management, as well as appropriate equipment, such as personal protective equipment (PPE), specialized ambulances and isolation area should be provided to ensure readiness and improved workforce performance.

Additionally, festival-specific MERS prevention and control protocol would be required as component of the general emergency plan. Reporting the absence of camel handlers as marker for sick-off may boost MERS surveillance initiatives. This may require daily attendance monitoring and follow-up phone call to verify reasons for absenteeism. Health education should reinforce avoidance of risky behaviours, such as camel riding and drinking of unpasteurized dairy products of camels. Active surveillance for other zoonosis should also be considered. Currently, Alkhurma haemorrhagic fever (AHF) is a notifiable zoonosis in Saudi Arabia. It is a tick borne viral illness that causes non-specific flu-like illness, neurologic and haemorrhagic symptoms in humans. Since the virus was first isolated in 1994, the majority $(>80 \%)$ of cases in Saudi Arabia have been reported in Najran Region. So far, no cases of the disease have been reported in Riyadh (festival city). The incidence rate of AHF per 100 ooo population in the country reduced from 0.33 in 2011 to 0.12 in 2016, with an overall case fatality rate of less than $1 \%(14,24)$. However, given the possible role of contact with livestock in the transmission of the virus to humans, there is need to prioritize the disease in future risk assessments.

The partnership with MEWA should also involve risk assessment for camel diseases, such as camelpox and infection by trypanosoma evensi, which are potential veterinary threats in the context of a camel festival. Camelpox is a highly infectious othorpox viral disease of camels. The symptoms of camelpox range from localized skin lesions to abortions and septicaemia in camels. Vaccination with a life-attenuated camel pox vaccine or the inactivated vaccine administered in booster doses provides long lasting immunity among inoculated camels (25). Trypanosomiasis is also an important disease of livestock, such as camels and horses caused by $\mathrm{T}$. evensi. The reported high mortality from the disease has huge economic implications in affected areas $(26,27)$ In Saudi Arabia, the control of T. evensi infection is achieved through prophylaxis and early treatment of symptomatic camels. Similarly, other rare diseases that affect both humans and camels potentially create an opportunity for sustained collaboration between the MoH and MEWA during the festival, to strengthen surveillance using the One Health approach. For example, plague manifests clinically in both camels and humans (28). Despite the absence of an epidemiological link between the festival and outbreaks of plague in Saudi Arabia, consumption of raw infected camel liver has been linked to cases of human plague in the country (29). $\mathrm{MoH}$ routine surveillance report indicated there were no cases of human plague in recent times (14). Yet, the disease remains an ever-present public health threat, which warrants a coordinated approach to prevention and control (30). 
With improved healthcare services in Saudi Arabia, it is unlikely that foodborne diseases outbreaks will result in significant mortality due to anticipated early intervention by the food safety teams in the MoH. However, such outbreaks may critically impugn legacy due to the wide media coverage of the event. Thus, the aim of health education should include promotion of hand hygiene, proper storage of cooked food and advice regarding early care-seeking for symptomatic individuals. The MoH ought to be involved in regulating and monitoring restaurants and food providers, to ensure they comply with food safety standards, including screening of workers for pathogenic organisms, such as salmonella typhi. Only two health units located in the contest area were designated for the festival. However, based on the incubation period of the frequently reported pathogens, typically within 4-8 hours, symptoms of foodborne diseases may present at night when participants have retired to their tents. Therefore, there is need to establish more health units to provide coverage for the tent/living area, and ensure round-theclock service delivery in the health facilities.

The extent of threat to life and property during masscasualty events may vary widely with the intensity of exposure and type of hazard. Determination of intensity and estimation of risks for certain hazards like terrorist activities and environmental hazards is beyond the scope of the $\mathrm{MoH}$ but dealing with the aftermath of these events, such as illnesses and injuries to participants, may well be the responsibility of the $\mathrm{MoH}$. Thus a multidisciplinary approach, involving stakeholders from the Civil Defence, Red Crescents, Municipality, $\mathrm{MoH}$ and event organizers would be required for preparedness and response to public health threats during the festival. Each stakeholder should be aware of their specific roles in the incident command system and be ready to perform individual functions in the festival's emergency plan if the need arises. Specialized teams should be ready to manage complex situations, such as chemical and biological attacks and bomb explosions.

Additionally, specific interventions should be implemented to address critical areas. These may include the installation of speed bumps and traffic camera in designated locations which may help to reduce the frequency and intensity of RTAs. In addition to these measures, the $\mathrm{MoH}$ should address the risks of falls and kicks by camels during future assessments, report on these injuries even in the absence of cases (zero reporting) and provide safety protocols to prevent such injuries during the festival. No cases of trauma from falls and kicks by camels were reported during the previous camel festivals. Essential medical supplies at the festival health facilities should include medications for snake and scorpion bite treatment and bronchodilators to relieve exacerbated bronchial asthma. Furthermore, event organizers should aim to balance misinformation circulating in social media, such as Twitter and Facebook, with facts due to the damaging effect of rumours on the reputation of MGs. In the case of the camel festival, while some social media users tweeted about the socio-cultural benefits of the festival, others expressed concern about gun violence and communal and family conflicts that could be generated by dissatisfaction with contest results. Organizers should pay attention to these concerns and resolve doubts through press briefings, interviews and official response to social media publications.

\section{Conclusion}

While the detection and control of unique health risks created by the interaction between humans and camels remains pertinent, prioritization of other sources of risks, such as demography of participants, festival location and climatic/weather conditions has some potential benefits; it allows the identification of diverse hazards that may pose significant threats. Using the all-hazard approach to mass gatherings risk assessment, the Jeddah tool facilitated the identification of foodborne diseases, zoonosis, such as MERS and brucellosis, as well as external causes of morbidity and mortality, such as bites and trauma, as the major public health threats at the camel festival. In addition to these health threats, the tool was proven useful for detecting the shortcomings in the mitigating capacity. Hence, the risk assessment recommended the need for multi-sectorial collaboration to strengthen the existing capacity, including disease surveillance, risk communication, essential infrastructure and health service delivery.

Funding: None.

Competing interests: None declared.

\section{Évaluation des risques sanitaires lors de rassemblements de masse : compte rendu du festival du chameau en Arabie saoudite}

\section{Résumé}

Contexte: À Riyad, le festival du chameau du Roi Abdel Aziz a pour but de montrer les rôles socio-culturels et économiques de cet animal au Moyen-Orient. Cet événement attire des visiteurs de nombreux pays de la Région.

Objectifs : Potentiellement, le rassemblement d'un grand nombre de visiteurs et d'animaux dans une zone géographique circonscrite, à l'occasion du festival annuel, a des implications majeures en termes de sécurité publique et de sécurité sanitaire et peut avoir d'importantes répercussions sur le plan de la santé. Ainsi, le ministère de la Santé, par l'intermédiaire du Centre mondial pour la médecine des rassemblements de masse, fondé en Arabie saoudite, a effectué une évaluation des risques sanitaires à l'occasion de l'édition 2017 du festival du chameau. Le présent article résume le processus d'évaluation des risques et met en exergue les conclusions et les recommandations de l'évaluation. 
Méthodes : Sur la base d'une approche multirisque, l'outil de Jeddah (reprenant l'outil d'évaluation des risques pour la santé élaboré par le Bureau régional de l'Organisation mondiale de la Santé pour la Méditerranée orientale) a été adapté pour mener l'évaluation des risques. Cet outil stipule que le risque est directement proportionnel au produit de l'ampleur des risques et de la vulnérabilité et inversement proportionnel à la capacité de prise en charge.

Résultats : Les causes externes de morbidité et de mortalité, telles que les incendies et les accidents de la circulation routière, ont été classées parmi les risques élevés. À l'inverse, la brucellose, les maladies d'origine alimentaire et le syndrome respiratoire du Moyen-Orient figuraient parmi les risques modérés. La fièvre de la vallée du Rift constituait un risque faible.

Conclusions : L'évaluation des risques effectuée dans le cadre du festival du chameau met en évidence la nécessité de s'appuyer sur une approche multirisques afin d'évaluer les risques liés aux rassemblements de masse. Une collaboration multisectorielle est nécessaire afin de renforcer les capacités existantes, notamment en matière de surveillance des maladies.

$$
\begin{aligned}
& \text { تقدير المخاطر الصحية في التجمعات الجماهيرية: تقرير عن مهرجان الإبل في المملكة العربية السعودية } \\
& \text { كنجسلي بيه، أحمد الجنايني، صابر يزلي، مأمون مالك، هاني جوخدار، عبد الله عسيري، بدرية. العتيبي }
\end{aligned}
$$

الخلفية: هيدف مهر جان الملك عبد العزيز للإبل في الرياض إلى إبراز الأدوار الثقافية الاجتماعية والاقتصادية للإبل في الشرق الأوسط، ويجذب هذا المهر جان زواراً من كثير من بلدان الإقليم. الإنئ.

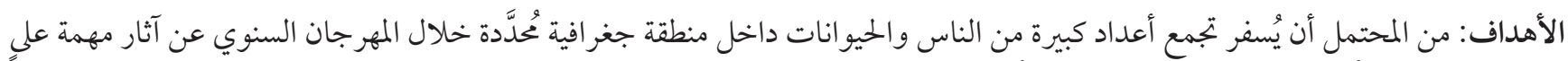

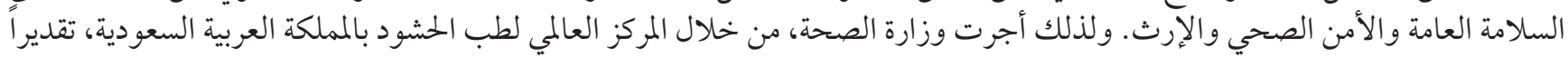

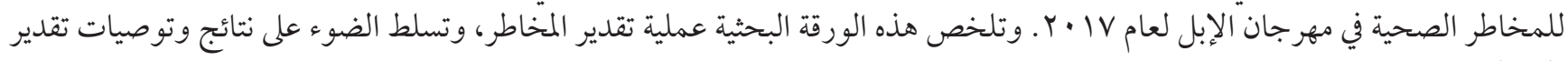
المخاطر .

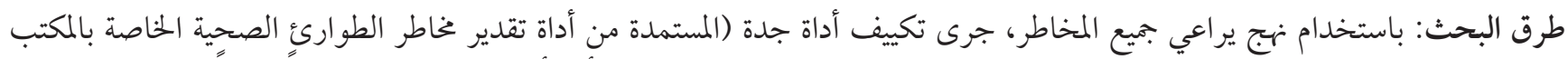

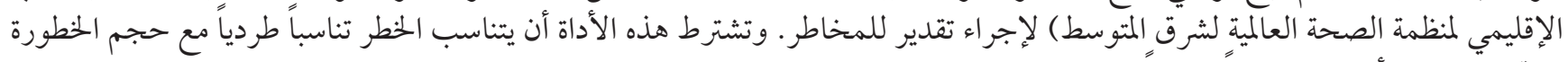

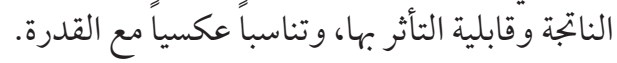

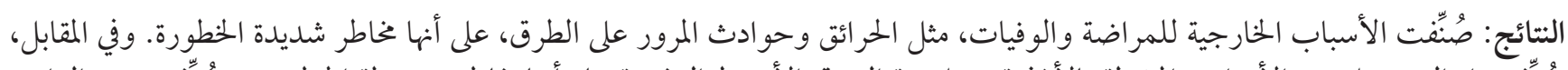

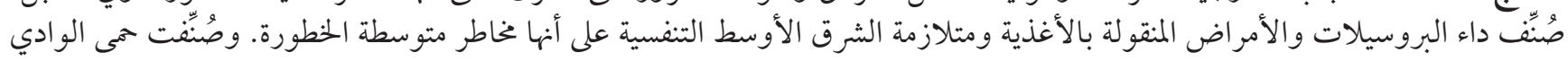
المتصدع على أنها من المخاطر القليلة الخطورة.

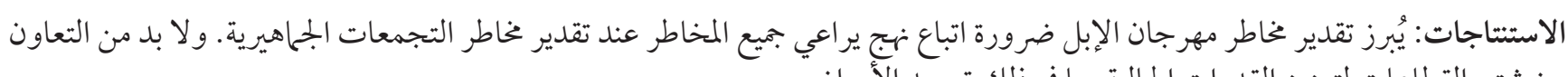

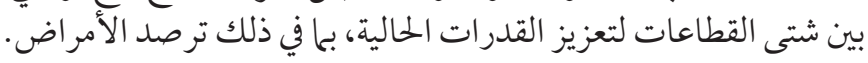

\section{References}

1. World Health Organization. Communicable disease alert and response for mass gatherings: key considerations. Geneva: World Health Organization; 2008 (http://www.who.int/csr/Mass_gatherings2.pdf, accessed 7 March 2017).

2. BM, Yezli S, Bin Saeed AA, Turkestani A, Alawam AH, Bieh KL. Strengthening health security at the Hajj mass gatherings: characteristics of the infectious diseases surveillance systems operational during the 2015 Hajj. J Travel Med. 2017;24(3). http://dx.doi.org/10.1093/jtm/taw087

3. Gazette S. Riyadh to host world's biggest heritage festival, 7 February, 2017 Saudi Gazette (http://saudigazette.com.sa/article/172525/?page=1, accessed 7 March 2017).

4. Memish ZA, Assiri A, Tuekestani A, Yezli S, Al Masri M, Charrel R, et al. Mass gathering and globalization of respiratory pathogens during the 2013 Hajj. Clin Microbiol Infect. 2015. 2015 Jun;21(6):571.e1-8. http://dx.doi.org/10.1016/j.cmi.2015.02.008

5. World Health Organization. Public Health for Mass Gatherings: Key Considerations. Geneva: World Health Organization; 2015 (http://apps.who.int/iris/bitstream/handle/10665/162109/WHO_HSE_GCR_2015.5_eng.pdf;jsessionid=A8287F2B866D6A7DF9FDAF74E2712A50?sequence=1).

6. ISDR. Hyogo framework for action 2005-2015: building the resilience of nations and communities to disasters. in Extract from the final report of the World Conference on Disaster Reduction (A/CONF. 206/6). 2005.

7 Ministry of Health. Command and Control Centre: MERSCoV update. Riyadh: Ministry of Health Kingdom of Saudi Arabia; 2017 (http://www.moh.gov.sa/en/CCC/PressReleases/Pages/statistics, accessed 2 November 2017). 
8. WHO. Frequently Asked Questions on Middle East respiratory syndrome coronavirus (MERS-CoV). Geneva: World Health Organization; 2015 (http://www.who.int/csr/disease/coronavirus_infections/faq/en/, accessed 7 March 2017).

9. Omrani AS, Al-Tawfiq JA, Memish ZA. Middle East respiratory syndrome coronavirus (MERS-CoV): animal to human interaction. Pathog Glob Health. 2015;109(8):354-62. http://dx.doi.org/10.1080/20477724.2015.1122852

10. World Health Organization. Rift Valley fever fact sheet. Geneva: World Health Organization; 2016 (http://www.who.int/mediacentre/factsheets/fs207/en/,accessed 7 March 2017).

11. Anyamba A, Chretien J-P, Formenty PBH, Small J, Tucker CJ, Malone JL, et al. Rift Valley Fever Potential, Arabian Peninsula. Emerg Infect Dis. 2006;12(3):518-20. http://dx.doi.org/10.3201/eid1203.050973

12. Madani TA, Al-Mazrou YY, Al-Jeffri MH, Mishkhas AA, Al-Rabeah AM, Turkistani AM, et al. Rift Valley Fever Epidemic in Saudi Arabia: Epidemiological, Clinical, and Laboratory Characteristics. Clin Infect Dis. 2003;37(8):1084-92. http://dx.doi. $\operatorname{org} / 10.1086 / 378747$

13. Aloufi AD, Memish ZA, Assiri AM, McNabb SJ. Trends of reported human cases of brucellosis, Kingdom of Saudi Arabia, 20042012. J Epidemiol Glob Health. 2016;6(1):11-8. http://dx.doi.org/10.1016/j.jegh.2015.09.001

14. Ministry of Health, Statistical yearbook 1437, Kingdom of Saudi Arabia 2016.

15. Folger AT, Davidson CS, Jacob LK, Allingham P, Kesterman GE. Outbreak of salmonellosis associated with consumption of pulled pork at a church festival - Hamilton County, Ohio, 2010. Center for Disease Control. MMWR Morb Mortal Wkly Rep. 2014;62(51-52):1045-7.

16. Wilson E. Foodborne illness and seasonality related to mobile food sources at festivals and group gatherings in the state of Georgia. J Environ Health. 2015;77(7):8-11, quiz 54.

17. Ahmed QA, Arabi YM, Memish ZA. Health risks at the Hajj. Lancet. 2006;367(9515):1008-15. http://dx.doi.org/10.1016/So1406736(06)68429-8

18. Abd El Ghany M, Alsomali M, Almasri M, Padron Regalado E, Naeem R, Tukestani A, et al. Enteric Infections Circulating during Hajj Seasons, 2011-2013. Emerg Infect Dis. 2017;23(10):1640-1649. https://dx.doi.org/10.3201/eid2310.161642

19. Ministry of Health. 1437 Hajj Strategic health risk assessment report. Riyadh: Ministry of Health Kingdom of Saudi Arabia; 2016.

20. Mansuri FA, Al-Zalabani AH, Zalat MM, Qabshawi RI. Road safety and road traffic accidents in Saudi Arabia: A systematic review of existing evidence. Saudi Med J. 2015;36(4):418-24. http://dx.doi.org/10.15537/smj.2015.4.10003

21. INFORM. Country risk profiles for 191 countries. 2017 (http://www.inform-index.org/Countries/Country-profiles/iso3/SAU).

22. Haidar, Nasser Ali, and Eric Deitch. Snake bites in the Arabian Peninsula, a review article. Journal of arid environments, v. 112:159-164. http://dx.doi.org/10.1016/j.jaridenv.2014.04.010

23. Al-Sadoon MK. Snake bite envenomation in Riyadh province of Saudi Arabia over the period (2005-2010). Saudi J Biol Sci. 2015;22(2):198-203. http://dx.doi.org/10.1016/j.sjbs.2014.09.008

24. Memish ZA, Fagbo SF, Ali AO, AlHakeem R, Elnagi FM, Bamgboye EA. Is the epidemiology of alkhurma hemorrhagic fever changing?: A three-year overview in Saudi Arabia. PLoS One. 2014;9(2):e85564. http://dx.doi.org/10.1371/journal.pone.0085564

25. Dahiya SS, Kumar S, Mehta SC, Narnaware SD, Singh R, Tuteja FC. Camelpox: A brief review on its epidemiology, current status and challenges. Acta Trop. 2016;158:32-8. http://dx.doi.org/10.1016/j.actatropica.2016.02.014

26. Amoudi M, Al-Yousif M, Al-Shawa Y. Morphological forms of Trypanosoma evansi from blood of Arabian camel (Camelus dromedarius) in the Riyadh metropolitan areas. J Egypt Soc Parasitol. 2011;41(1):29-33.

27. Omer OH, Magzoub M, Haroun EM, Mahmoud OM, Abdel Hamid YM. Diagnosis of Trypanosoma evansi in Saudi Arabian Camels (Camelus dromedarius) by the passive haemagglutination test and Ag-ELISA. Zentralbl Veterinarmed B. 1998 Dec;45(10):627-33 PMID: 9916554

28 Christie A, Chen T, Elberg SS. Plague in camels and goats: their role in human epidemics. J Infect Dis. 1980;141(6):724-6. http://dx.doi.org/10.1093/infdis/141.6.724

29. Saeed AAB, Al-Hamdan NA, Fontaine RE. Plague from eating raw camel liver. Emerg Infect Dis. 2005;11(9):1456-7. http://dx. doi.org/10.3201/eid1109.050081

30. Stenseth NC, Atshabar BB, Begon M, Belmain SR, Bertherat E, Carniel E, et al. Plague: past, present, and future. PLoS Med. 2008;5(1):e3. http://dx.doi.org/10.1371/journal.pmed.0050003 